\title{
20 years \\ of the Faculty of Finance and Accounting at the University of Economics, Prague
}

\section{Dear readers,}

in our country when we talk about the age of the university, everyone likely recall in memory the year 1348, which we have indelible put together with the founding of Charles University at history lessons. In comparison with this the year 1991, in which Faculty of Finance and Accounting was founded, it may seem though as yesterday, but it certainly is the reason for some hindsight.

Establishment of the Faculty was the result of post-revolutionary changes in the University of Economics, Prague. The basis of the new faculty was at that time placed by two major departments - the Department of Finance and Credit and Department of Accounting, which had operated at different faculties. While the Department of Finance and Credit was part of the Faculty of National Economy then Department of Accounting came under existing Faculty of Management. Also Department of Methodology Teaching has become a part of the new faculty because of the traditional reasons and professional and personal relationship.

The idea to create an entirely new faculty based on links between finance and accounting was quite brave. The role of finance and accounting in the centrally planned economy was significantly suppressed, and therefore interest of students as well as acceptance of faculty by professionals and the general public was largely unknown.

Already shortly after the faculty founding it was showed that this was more than just correct step. The Faculty quickly came to the attention as one of the leading economic faculties in our country. Fields of study offered by the faculty was high demanded and many of the faculty 
members had significantly contributed to economic transformation and the formation of a new economic system in Czechoslovakia.

The main reasons for the successful development of the faculty can be found in two areas. On the one hand, it was the linking of two disciplines - finance and accounting - which start playing a crucial role in the economy after years of vegetating and which knowledge was a prerequisite for understanding the functioning market economy. The lack of knowledge of both disciplines in the general professional public on the one hand and the necessity for every economist in the market economy on the other hand, were the cause of high interest in a full-time study, as well as many postgraduate courses designed for university graduates from the socialist era.

However more fundamental role was played by people who built up both departments and who eventually became leaders in the newly established Faculty and its departments. Despite many years of isolation from Western economic theory and practice they were able to quickly form the content of study programs based on the concept of standard finance and accounting, prepare new textbooks and establish international contacts. List of names of all who contributed to an emergence of a new faculty would be very long. At least it must be mentioned Professor Vladimir Pilný who was in the spring in 1991 elected as the head of the faculty as its first dean, for all of them.

Successful development of the faculty which took twenty years could be mostly illustrated by the hundreds of graduates who are able to push through at the various places. The Faculty boasts a long time virtually zero unemployment of its graduates who are also very positive about the fact how faculty prepare them for future occupation. It is obvious that well-prepared graduates can bring up only a good quality school with a stable team of highly knowledgeable experts recognized both in academia and in economic practice. The Faculty has accreditation for all three types of study, as well as for procedures for conferring "Venium docendi" (associate professors) and for appointment of professors just because of them. It could not be forget that the faculty is displayed at prominent places in the ranking of economic faculties every year, which is regularly draw in recent years in our country.

Twentieth in human life generally means that the best years are coming when the one has desire to change the world, push through and 
PREFACE - Dvořák, P.: 20 years of the Faculty of Finance and Accounting,

University of Economics, Prague.

prove something. As I have indicated in the introduction, the twentieth in the life of the school represent only the first step towards building a strong tradition and its place in competition with other schools. However, our faculty is definitely not missing desire to enhance its reputation both domestically and internationally. The Faculty certainly has prerequisites because of its academic staff as well as its students. And it would be a shame if it would not be able to use them. After all, it is our duty to those who founded our faculty twenty years ago.

doc. Ing. Petr Dvorak, Ph.D.

Dean

Faculty of Finance and Accounting, University of Economics, Prague 